\title{
Off pump mitral valve repair
}

\author{
Kestutis Rucinskas ${ }^{1}$, Vilius Janusauskas ${ }^{1 *}$, Diana Zakarkaite ${ }^{1}$, Rita Kramena', Gabija Janaviciute ${ }^{1}$, Agne Drasutiene ${ }^{1}$ \\ Robertas Stasys Samalavicius ${ }^{2}$, Audrius Aidietis ${ }^{1}$ \\ From World Society of Cardiothoracic Surgeons 25th Anniversary Congress, Edinburgh \\ Edinburgh, UK. 19-22 September 2015
}

\section{Background/Introduction}

The NeoChord DS1000 is a disposable device used to replace damaged chordae by delivering artificial chordae tendinae in a beating heart through small anterolateral thoracotomy. It gives alternative approach in treating degenerative mitral valve insufficiency.

\section{Aims/Objectives}

To assess safety and efficacy in treating patients with off-pump transapical neochord implantation in Vilnius University.

\section{Method}

60 patients had underwent off pump transapical neochord implantation. Patients were followed up to 1 year with clinical and echocardioscopic examination.

\section{Results}

Out of 60 patients 48 (80\%) had chordae implanted only to P2 segment. 2 (3\%) patients had chordae implanted only to A2 segment. All other patients had chordae implanted to multiple segments. The average patient age was $60 \pm 12$ years, Euroscore II $-1,2 \pm 1 \%$. Median duration of operation was $129 \pm 27 \mathrm{~min}$. The mean intraoperative blood loss was $700 \pm 500 \mathrm{ml}$, mean postoperative drainage was $230 \pm 120 \mathrm{ml}$. Three (6\%) patients needed RBC transfusion, 1 (2\%) patient needed FFP transfusion. One patient required permanent pacemaker implantation due to sick sinus syndrome. There were no re-explorations for bleeding, strokes, new renal failure, wound infections or deaths. Acute procedure success was achieved in 58 (97\%) of patients.52 patients had reached 6 months follow up and 33 patients have reached 12 months follow up. In patients with P2 prolapse without prolapse extension towards the commissures or central component to regurgitant jet or lack of

${ }^{1}$ Department of Cardiovascular Disease, Vilnius University, Vilnius, Lithuania Full list of author information is available at the end of the article central cooptation the mitral valve insufficiency less than $2+$ remained in $94 \%$ (36 out of 38) patients at six months and $92 \%$ (22 out 24 ) at 12 months follow up. In patients with prolapse extension towards the commissures or with central component to regurgitant jet or lack of central cooptation the mitral valve insufficiency less than $2+$ was achieved in $50 \%$ (6 out of 12) patients at six months and 50\% (4 out 8 ) at 12 months follow up.

\section{Discussion/Conclusion}

Off-pump transapical implantation of artificial chordae with NeoChord device is a safe method for the treatment of mitral valve insufficiency and preserves conventional MV repair treatment options if unsuccessful.

\section{Authors' details}

${ }^{1}$ Department of Cardiovascular Disease, Vilnius University, Vilnius, Lithuania. ${ }^{2}$ Department of Intensive Care, Centre of Anaesthesia, Intensive Care and

Pain Management, Vilnius University, Vilnius, Lithuania.

Published: 16 December 2015

doi:10.1186/1749-8090-10-S1-A318

Cite this article as: Rucinskas et al: Off pump mitral valve repair. Journal of Cardiothoracic Surgery 2015 10(Suppl 1):A318.

Submit your next manuscript to BioMed Central and take full advantage of:

- Convenient online submission

- Thorough peer review

- No space constraints or color figure charges

- Immediate publication on acceptance

- Inclusion in PubMed, CAS, Scopus and Google Scholar

- Research which is freely available for redistribution 